\title{
Informal Personal Financing of Entrepreneurs: Gender Characteristics
}

\author{
Iuliia S. Pinkovetskaia ${ }^{1, *}$, Anton V. Lebedev², Olga V. Slugina ${ }^{2}$, Diego Felipe Arbelaez Campillo ${ }^{3}$, \\ Magda Julissa Rojas Bahamon ${ }^{4}$ \\ ${ }^{1}$ Department of the Economic Analysis and State Management, Institute of Economics and Business, Ulyanovsk State University, \\ Ulyanovsk, 432000, Russia \\ ${ }^{2}$ Department of Foreign Languages, National Research Ogarev Mordovia State University, Saransk, 430005, Russia \\ ${ }^{3}$ Research Group Languages, Representations and Education, University Amazonia, Florencia, Colombia \\ ${ }^{4}$ Educational Institution Jorge Eliecer Gaitán, University Amazonia, Florencia, Colombia
}

Received April 23, 2021; Revised June 10, 2021; Accepted June 25, 2021

\section{Cite This Paper in the following Citation Styles}

(a): [1] Iuliia S. Pinkovetskaia, Anton V. Lebedev, Olga V. Slugina, Diego Felipe Arbelaez Campillo, Magda Julissa Rojas Bahamon, "Informal Personal Financing of Entrepreneurs: Gender Characteristics," Universal Journal of Accounting and Finance, Vol. 9, No. 3, pp. 442 - 449, 2021. DOI: 10.13189/ujaf.2021.090319.

(b): Iuliia S. Pinkovetskaia, Anton V. Lebedev, Olga V. Slugina, Diego Felipe Arbelaez Campillo, Magda Julissa Rojas Bahamon (2021). Informal Personal Financing of Entrepreneurs: Gender Characteristics. Universal Journal of Accounting and Finance, 9(3), 442 - 449. DOI: 10.13189/ujaf.2021.090319.

Copyright $(2021$ by authors, all rights reserved. Authors agree that this article remains permanently open access under the terms of the Creative Commons Attribution License 4.0 International License

\begin{abstract}
The Aim of the article is in the assess indicators characterizing informal personal financing of entrepreneurs in different countries. Initial information used in our research is the data obtained in the course of the survey habitats of various countries (Global Entrepreneurship Monitor). In the course of the study we consider the indicators characterizing investment activity of men and women on three options including financing of the entrepreneurs who are their relatives, colleagues, friends and acquaintances. The assessment of the levels of nine indicators used economic-mathematical modeling based on density functions of normal distribution. The use of these functions allows defining medium values and ranges changes in considered indexes typical for most countries. In addition, the survey identifies the national economies which are characterized by the maximum and minimum data nine indicators. The study demonstrates that there is a gender gap in the data for various states. The scientific novelty and originality of this research are as follows: the indicators of external investment in firms created by entrepreneurs in different countries have been estimated; the assessment of nine indicators characterizing external investments for start-up entrepreneurs has been modeled; presents a high difference in the values of considered indexes in different countries has been shown; countries with maximum and minimum values of each
\end{abstract}

indicator. It has been proven: proportion in a number of involved men in informal financing of created SMEs established by their relatives in most countries is lower than the same indicator of women, and men proportion involved in informal financing of the new SMEs created by their colleagues, as well as friends and neighbors in most countries is higher than the same indicator of women. Further research can be aimed at detailing the structure of informal financing recipients among entrepreneurs.

Keywords Small and Medium Enterprises, Investment in Entrepreneurship, Informal Financing, Gender Gap, Participation of Women and Men in Financing

\section{Introduction}

The relevance of studying the problem of investment creation of new small and medium enterprises (SMEs) by entrepreneurs is emphasized in many scientific studies carried out in recent years. One of the most difficult problems hindering the creation of such enterprises is the lack of sufficient financial resources for the start-up entrepreneurs who create these enterprises $[1,2,3,4,5]$. 
The situation is deteriorating due to the difficulty for start-up entrepreneurs to obtain financial support from banks, that is, to use formal credit mechanisms. This is indicated by multiple authors [6, 7]. They draw attention to the lack of real estate and other assets necessary for secured bank loans. Financial restrictions can be especially severe when intangible assets are used in accepted business models, as these models are specific to certain firms and they are difficult to be used as collateral in traditional management of debt [8]. In addition, the crisis phenomena, typical of recent times, increase the bank requirements for the issuance of credits. In the context of crises, banking credit constraints faced by SMEs in most countries have highlighted the vulnerability of the SME sector [9].

In the twenty-first century, it is important to attract funds from individuals for financing the new SMEs in many countries. This phenomenon is called external financing of entrepreneurs. Our paper deals with such an urgent problem as the assessment of the current levels of informal financing of the business sector in various countries, which should improve the understanding of the entire range of financial instruments and new approaches to investment in SMEs, an alternative to the traditional bank lending.

Entrepreneurs in most countries usually start a business with their money, followed by the funds from relatives and friends, that is, informal investments $[10,11]$. Scientific publications of recent years have also paid much attention to calling for more systematic consideration of start-up entrepreneurs' external financing based on informal investments. The following works published in recent years and considering the theoretical and practical aspects of increasing the efficiency of informal investments in small and medium businesses can be noted $[12,13]$.

It is significant to discuss gender regularities in such funding. That is, studying the characteristics of informal investments in the new SMEs by women and men. In addition, in our opinion, it is logical to determine whether there are gender differences in the actions of women and men involved in the process of financing the start of entrepreneurial activity. In nowadays researches on the gender characteristics of informal investment in SMEs paid not enough attention.

In our research, we answer the following questions:

1. What is the proportion of female investors financing the new SMEs created by their relatives in all women who financed entrepreneurship?

2. What is the proportion of male investors financing the new SMEs created by their relatives in all men who financed entrepreneurship?

3. Is there gender differences in the informal financing of SMEs created by their relatives?

4. What is the proportion of female investors financing the new SMEs created by their colleagues in the total number of women who financed entrepreneurship?
5. What is the proportion of male investors financing the new SMEs created by their colleagues in the total number of men who financed entrepreneurship?

6. Is there a gender gap between the proportion of women and men who informally finance the new SMEs created by colleagues?

7. What is the proportion of female investors financing the new SMEs created by friends and neighbors in the total number of women who finance entrepreneurship?

8. What is the proportion of male investors financing the creation of the new SMEs by friends and neighbors in all men who finance entrepreneurship?

9. Is there gender differences in the informal financing of SMEs created by friends and neighbors?

The aim of the paper is to assess indicators characterizing informal finance on the above options for the new SMEs by male and female investors. Meanwhile, we have solved the following tasks.

\section{Review of Literature}

Discuss characteristics of SMEs have shown the feasibility of dividing external financing into formal and informal. In this context, formal financing includes the loans received from financial and credit organizations, and informal financing involves the funds acquired from relatives, friends, or colleagues [14]. Formal financing is based on strict requirements and conditions, including the existence of significant guarantees for the repayment of loans. Informal financing is built on the availability of soft (private) information and principles based on personal relationships. Therefore, entrepreneurs often prefer to use informal financing for their businesses [15], since it is associated with less time, lower transaction costs and no collateral requirements. It should be noted that formal creditors have limited information about entrepreneurs and those entrepreneurs who are unable to provide collateral are automatically weeded out and forced to look for informal investors [16]. Therefore, many researchers assume that informal funding is preferable to formal funding. Researchers commonly refer to the financing of family, friends and relatives as the financial choice of their research subjects $[17,18]$.

Informal funding has been considered in a number of research studies. Thus, works $[14,19]$ reveal that using informal investment is widely used in Chinese SMEs. In the work [20], the example of Brazilian entrepreneurs indicates that it is advisable to switch from informal financing to banking at the later stages of SME development. The study [15] demonstrates that a balanced use of both financing options is logical for small businesses. The research [21] was concluded the predominance of informal sources in the financing of early-stage entrepreneurs.

Social capital and entrepreneurial networks are the important factors stimulating informal investment [22, 23]. 
The work [24] emphasizes that entrepreneurs should use their built on social and economic networks (with businessmen) to ensure investment in their enterprises. The personal social capital created by entrepreneurs' previous production activities can make it easier to find informal investors [25]. It increases trust and removes barriers to informal finance contracts [26].

Regional researches showed the specific institutional rules with the use of financing, including country-specific laws and regulations [27]. Governance quality forms the financial management strategy [28]. In addition, traditions, values and established business regulations have a significant impact on solving specific problems [29].

\section{Materials and Methods}

Informal financing of the new SMEs is carried out by citizens of different countries of their own free will and with the trust in the entrepreneurs who own these enterprises. In this case, the main investors, as indicated in a number of studies [30,31], are relatives, colleagues, friends and neighbors. Our study examines the assessment of nine indicators characterizing the gender-specific aspects of informal investment in SMEs in 59 countries between 2018 and 2019:

- the proportion of female investors financing the new SMEs created by their relatives in the total number of women who financed entrepreneurial activities (first indicator);

- the proportion of male investors financing the new SMEs created by their relatives in the total number of men who finance entrepreneurial activities (second indicator);

- the relation of data on indicators of female and male participation in informal financing of the new SMEs created by relatives (third indicator);

- the proportion of female investors financing the creation of the new SMEs by their colleagues in the total number of women who finance entrepreneurial activities (fourth indicator);

- the proportion of male investors financing the creation of the new SMEs by their colleagues in the total number of men who finance entrepreneurial activities (fifth indicator);

- the relation of data on indicators of female and male participation in informal financing of the new SMEs created by colleagues (sixth indicator);

- the proportion of female investors financing the creation of the new SMEs by friends and neighbors in the total number of women who finance entrepreneurial activities (seventh indicator);

- the proportion of male investors financing the creation of the new SMEs by friends and neighbors in the total number of men who finance entrepreneurial activities (eighth indicator); the ratio of the values of indicators of female and male participation in informal financing of the new SMEs created by friends and neighbors (ninth indicator).

The first three indicators correspond to the first of the considered informal financing options, the indicators from the fourth to the sixth - to the second option, and the indicators from the seventh to the ninth - to the third option.

The initial information used in our study is the data obtained from the implementation of the Global Entrepreneurship Monitor project of 2018-2019 [32].

Our study includes the testing of the three next hypotheses:

- first hypothesis - information on nine considered indicators have a serious difference in various states;

- second hypothesis - on the data of nine indicators does not significantly influence the geographic location of states;

- third hypothesis - level of income of the population in the countries under consideration does not significantly influence the values of each of the nine indicators.

Assessment data on nine considered indicators is relying on economic-mathematical modeling of the initial practical information. As such models we use density functions of normal distribution and such methodic for development is used for evaluating data on the indicators in the paper [33].

Sets of entrepreneurs formed on a territorial basis include their significant number. This, as well as the presence of various factors that influence on the productivity of entrepreneurs, suggests the probabilistic (stochastic) nature of the creation indicators values describing the enterprise's totality. The study of phenomena and processes whose parameters are formed as a result of the combined influence of many factors acting additively and independently of each other can be carried out using the law of normal distribution.

The density of probability is non-negative over the entire range of variation, because this is a derivative of a non-decreasing function. Density distribution function describes as whole information on the random variable. Basic numerous information, characterize certain random variable is:

- characteristics of a random variable place, i.e. mode, median, mathematical expectation and for density functions of normal distribution these three characteristics are equal to each other;

- the characteristic that is called the mean square deviation, i.e. spread of random variable near average value;

- the coefficients of skewness and kurtosis for normal distribution are equal to zero.

Mathematical models development describing the distribution of the indicator that describes the totality of 
organizations with the use of density the functions of normal distribution is based on construction such histograms. With a wide quantity of practical source data (40 and more), we can group this information into intervals to make more comfortable work with information. To make so, the range data of indicators is separated into the determined number of intervals. We chose intervals number on a variety of indicators and on regularity of distribution depends on small extent of random effects.

The obtained functions give us opportunity to evaluate medium values each of nine indicators in the states under consideration, also their variation typical for most countries. Besides, research identifies countries where considered indicators are higher than maximum and lower than minimum limits of distances. Valid distances of indicators values in 68 percent of states are based on average values and corresponding standard deviations of indexes. The Llower limit of range is equal to the difference between medium value and standard deviation, and their sum is an upper limit.

\section{Results of the Calculation Experiment}

Fragment describing the share of various types informal financing men and women in whole quantity of early entrepreneurs demonstrate Table 1.

In the course of the computational experiment, we carry out the economic-mathematical modeling. Functions (y) show distributions variables $(\mathrm{x}, \%)$ in 59 states are below:

- the proportion of female investors financing the creation of the new SMEs by their relatives in the total number of women who finance entrepreneurial activities

$$
y_{1}\left(x_{1}\right)=\frac{787.14}{16.51 \times \sqrt{2 \pi}} \cdot e^{\frac{-\left(x_{1}-64.59\right)^{2}}{2 \times 16.51 \times 16.51}}
$$

- the proportion of male investors financing the creation of the new SMEs by their relatives in the total number of men who finance entrepreneurial activity

$$
y_{2}\left(x_{2}\right)=\frac{797.50}{17.99 \times \sqrt{2 \pi}} \cdot e^{\frac{-\left(x_{2}-51.04\right)^{2}}{2 \times 17.99 \times 17.99}}
$$

- the ratio of the values of indicators of female and male participation in informal financing of the new SMEs created by relatives

$$
y_{3}\left(x_{3}\right)=\frac{16.57}{0.34 \times \sqrt{2 \pi}} \cdot e^{\frac{-\left(x_{3}-1.33\right)^{2}}{2 \times 0.34 \times 0.34}} ;
$$

the proportion of female investors financing the creation of the new SMEs by their colleagues in the total number of women who finance entrepreneurial activities

$$
y_{4}\left(x_{4}\right)=\frac{154.67}{5.46 \times \sqrt{2 \pi}} \cdot e^{\frac{-\left(x_{4}-6.23\right)^{2}}{2 \times 5.46 \times 5.46}} ;
$$

- the proportion of male investors financing the creation of the new SMEs by their colleagues in the total number of men who finance entrepreneurial activity

$$
y_{5}\left(x_{5}\right)=\frac{180.44}{5.70 \times \sqrt{2 \pi}} \cdot e^{\frac{-\left(x_{5}-9.51\right)^{2}}{2 \times 5.70 \times 5.70}}
$$

the ratio of the values of indicators of female and male participation in informal financing of the new SMEs created by colleagues

$$
y_{6}\left(x_{6}\right)=\frac{16.13}{0.52 \times \sqrt{2 \pi}} \cdot e^{-\frac{\left(x_{6}-0.91\right)^{2}}{2 \times 0.52 \times 0.52}} ;
$$

Table 1. Fragment of informal financing information descriptive of early-stage entrepreneurs, $\%$

\begin{tabular}{|c|c|c|c|c|c|c|}
\hline \multirow{2}{*}{ Country } & \multicolumn{2}{|c|}{ Family, relative } & \multicolumn{2}{c|}{ Colleague } & \multicolumn{2}{c|}{ Friend, neighbor } \\
\cline { 2 - 7 } & Men & Women & Men & Women & Men & Women \\
\hline Angola & 47 & 66 & 9 & 1 & 10 & 37 \\
\hline Australia & 48 & 61 & 8 & 13 & 23 & 23 \\
\hline Austria & 28 & 42 & 7 & 7 & 15 & 12 \\
\hline $\begin{array}{c}\text { Bosnia \& } \\
\text { Herzegovina }\end{array}$ & 70 & 87 & 15 & 17 & 35 & 0 \\
\hline Brazil & 48 & 75 & $\ldots$ & $\ldots$ & $\ldots$ & \\
\hline$\ldots$ & $\ldots$ & $\ldots$ & $\ldots$ & & $\ldots$ \\
\hline
\end{tabular}

Source: The data in the table based on [32]. 
- the proportion of female investors financing the creation of the new SMEs by friends and neighbors in the total number of women who finance entrepreneurial activities

$$
y_{7}\left(x_{7}\right)=\frac{497.14}{10.12 \times \sqrt{2 \pi}} \cdot e^{-\frac{\left(x_{7}-19.67\right)^{2}}{2 \times 10.12 \times 10.12}} ;
$$

- the proportion of male investors financing the creation of the new SMEs by friends and neighbors in the total number of men who finance entrepreneurial activities

$$
y_{8}\left(x_{8}\right)=\frac{435.00}{10.46 \times \sqrt{2 \pi}} \cdot e^{-\frac{\left(x_{8}-28.79\right)^{2}}{2 \times 10.46 \times 10.46}} ;
$$

- the ratio of the values of indicators of female and male participation in informal financing of the new SMEs created by friends and neighbors

$$
y_{9}\left(x_{9}\right)=\frac{13.51}{0.30 \times \sqrt{2 \pi}} \cdot e^{-\frac{\left(x_{9}-0.69\right)^{2}}{2 \times 0.30 \times 0.30}} .
$$

The quality of functions (1)-(9) we tested using such criteria: by the Kolmogorov-Smirnov, the Pearson and the Shapiro-Wilk. Calculated values of the criteria are given in Table 2.

Table 2. Calculated values of criteria

\begin{tabular}{|c|c|c|c|}
\hline \multirow{2}{*}{ Indicators } & \multicolumn{3}{|c|}{ Criteria } \\
\cline { 2 - 4 } & $\begin{array}{c}\text { The } \\
\text { Kolmogorov- } \\
\text { Smirnov test }\end{array}$ & $\begin{array}{c}\text { The } \\
\text { Pearson } \\
\text { test }\end{array}$ & $\begin{array}{c}\text { The } \\
\text { Shapiro-Wilk } \\
\text { test }\end{array}$ \\
\hline Indicator 1 & 0.08 & 2.36 & 0.97 \\
\hline Indicator 2 & 0.09 & 3.09 & 0.95 \\
\hline Indicator 3 & 0.08 & 4.01 & 0.96 \\
\hline Indicator 4 & 0.06 & 2.40 & 0.94 \\
\hline Indicator 5 & 0.09 & 4.22 & 0.96 \\
\hline Indicator 6 & 0.05 & 0.91 & 0.97 \\
\hline Indicator 7 & 0.04 & 3.24 & 0.98 \\
\hline Indicator 8 & 0.06 & 2.78 & 0.95 \\
\hline Indicator 9 & 0.08 & 3.29 & 0.94 \\
\hline
\end{tabular}

Source: The data in the table are based on the results of calculated functions.

Information given in column 2 of Table 2 showed that all calculated values are less than the critical value by the Kolmogorov-Smirnov test (0.174) at a significant level equal to 0.05 . Data in column 3 are less than the critical value of Pearson criterion (9.49). Data in column 4 exceed critical value 0.93 Shapiro-Wilk test with a significant level of 0.01 . Thus, the computational experiment showed that all nine developed functions have high quality.

Based on functions (1)-(9) we have an opportunity to define the number of regularities describing informal investing of early-stage entrepreneurs in the considered states. Mean indexes of indicators are in column 2 of Table 3. Column 3 of this table describes intervals change of indexes for most states.

Table 3. Indicators characterizing informal financing of the new SMEs

\begin{tabular}{|c|c|c|c|}
\hline Indicators & Mean values & $\begin{array}{c}\text { Standard } \\
\text { deviation }\end{array}$ & $\begin{array}{c}\text { Interval on most } \\
\text { countries }\end{array}$ \\
\hline Indicator 1, \% & 64.59 & 16.51 & $48.08-81.10$ \\
\hline Indicator 2, \% & 51.04 & 17.99 & $33.05-69.03$ \\
\hline Indicator 3 & 1.33 & 0.34 & $0.99-1.67$ \\
\hline Indicator 4, \% & 6.23 & 5.46 & $0.77-11.69$ \\
\hline Indicator 5, \% & 9.51 & 5.70 & $3.81-15.21$ \\
\hline Indicator 6 & 0.91 & 0.52 & $0.39-1.43$ \\
\hline Indicator 7, \% & 19.67 & 10.12 & $9.55-29.79$ \\
\hline Indicator 8, \% & 28.79 & 0.46 & $18.33-39.25$ \\
\hline Indicator 9 & 0.69 & 0.30 & $0.39-0.99$ \\
\hline
\end{tabular}

Source: Calculations were made by authors from functions (1) to (9).

Information presented in table 3 (column 2) shows: most of all investors finance their relatives, which seems logical. Besides, men are fewer likely informal finance in their relatives in comparison with women. On average in the overall sample almost $65 \%$ of female investors provided funding to entrepreneurs who are their relatives, compared with $51 \%$ of male investors. This pattern is typical for most countries, with the exception of France, India, Indonesia, Ecuador, Israel. Accordingly, the average value of the ratio of indicators of female and male participation in informal financing of the new SMEs created by relatives reaches 1.33 .

The assessment of the indicators characterizing the second option of informal SME financing, in which investments are allocated to colleagues, shows that men are more likely than women to finance their colleagues' firms. The average values of corresponding indicators for the countries under consideration are $6.2 \%$ for women and $9.5 \%$ for men. At the same time, in 4 states: Republic of Korea, Austria, Bulgaria, Italy, the activity of female investors is more than 1.5 times higher than the activity of men in financing SMEs created by their colleagues. In general, the average value of the relation of women and men participation rates in informal financing of the new SMEs created by colleagues is 0.91 .

The assessment of the indicators characterizing the third option of informal SME financing, in which investments are allocated to friends and neighbors, shows that male investors are more likely than women to invest in the firms of their friends and neighbors. The average values of the corresponding indicators for the countries under consideration are $19.67 \%$ for women and $28.79 \%$ for men. The opposite trend is observed only in such countries as France, the USA, Ecuador, India, Puerto Rico, Morocco. Thus, the average value of the relation of indicators of women and men's participation in informal financing of the new SMEs created by friends and neighbors is 0.69 . 
It should be noted that there is the fourth option for informal SME financing, involving the investments for setting up new firms are allocated to unfamiliar entrepreneurs. The data in Table 3 allow us to conclude that this option is used on average by $9.51 \%$ of female investors and $10.64 \%$ of male investors.

For testing hypothesis 1 , the analysis of information in column 3 (table 3 ) is conducted. Analysis indicates the high differentiation in values for each of nine indexes in the considered countries. Consequently, hypothesis 1 has been confirmed.
It is interesting to note that a correlation was found between indicators 1 and 2, which is 0.75 and between indicators 4 and 5 , which is 0.65 .

At the next stage, states with maximum and minimum values of each indicator are identified. High values exceed the upper limits of ranges indicated in column 3 of Table 3 and low values are less than lower limits of the indicated ranges. The results of this analysis are in Table 4. Along with the lists of states, this table shows a subdivision of the identified states by their geographic place and level of income of the population.

Table 4. States with maximum and minimum values of indicators

\begin{tabular}{|c|c|c|}
\hline Indicators & Maximum & Minimum \\
\hline 1 & 2 & 3 \\
\hline Indicator 1 & $\begin{array}{l}\text { States: Thailand, Greece, Argentina, Peru, Bosnia and } \\
\text { Herzegovina, Morocco, Lebanon, Poland, Madagascar. } \\
\text { Location: Europe (three states), Asia (two states), Africa } \\
\text { (two states), Latin America (two states). Population income: } \\
\text { high (three states), medium (four states), low (two states). }\end{array}$ & $\begin{array}{l}\text { States: France, Taiwan, India, Sweden, Austria, USA, } \\
\text { Kazakhstan, Germany. Location: Europe (four states), Asia } \\
\text { (three states), North America (one state). } \\
\text { Population income: high (six states), medium (one state), low } \\
\text { (one state). }\end{array}$ \\
\hline Indicator 2 & $\begin{array}{l}\text { States: Ecuador, Indonesia, Puerto Rico, Peru, Lebanon, } \\
\text { Poland, Morocco, Madagascar. Location: Europe (one } \\
\text { state), Latin America (three states), Asia (two states), Africa } \\
\text { (two states). Population income: high (two states), medium } \\
\text { (three states), low (three states). }\end{array}$ & $\begin{array}{l}\text { States: Taiwan, Republic of Korea, Sweden, United Arab } \\
\text { Emirates, Austria, Luxembourg, Great Britain, Turkey. } \\
\text { Location: Europe (four states), Asia (four states). Population } \\
\text { income: high (seven states), medium (one state). }\end{array}$ \\
\hline Indicator 3 & $\begin{array}{l}\text { States: Republic of Korea, Turkey, Italy, Slovenia, UAE, } \\
\text { Latvia, Ireland, Taiwan. Location: Europe (four states), } \\
\text { Asia (four states). Population income: high (seven states), } \\
\text { medium (one state). }\end{array}$ & $\begin{array}{l}\text { States: France, India, Indonesia, Ecuador, Israel. } \\
\text { Location: Europe (one state), Asia (three states), Latin } \\
\text { America (one state). Population income: high (two states), } \\
\text { medium (one state), low (two states). }\end{array}$ \\
\hline Indicator 4 & $\begin{array}{l}\text { States: China, Saudi Arabia, India, Kazakhstan, Brazil, } \\
\text { Italy, France, Republic of Korea, Indonesia, Canada. } \\
\text { Location: Europe (two states), Asia (six states), Latin } \\
\text { America (one state), North America (one state). Population } \\
\text { income: high (five states), medium (three states), low (two } \\
\text { states). }\end{array}$ & $\begin{array}{l}\text { States: Croatia, Cyprus, Egypt, Germany, Greece, Ireland, } \\
\text { South Africa. Location: Europe (five states), Africa (two } \\
\text { states). Population income: high (five states), medium (one } \\
\text { state), low (one state). }\end{array}$ \\
\hline Indicator 5 & $\begin{array}{l}\text { States: Malaysia, Bosnia and Herzegovina, Saudi Arabia, } \\
\text { Canada, UAE, Mexico, Indonesia, Turkey, } \\
\text { France. Location: Europe (two states), Asia (five states), } \\
\text { North America (one state), Latin America (one state). } \\
\text { Population income: high (five states), medium (two states), } \\
\text { low (two states). }\end{array}$ & $\begin{array}{l}\text { States: Poland, Taiwan, Japan, Morocco, Bulgaria, Argentina, } \\
\text { Lebanon, Switzerland, Guatemala. Location: Europe (three } \\
\text { states), Latin America (two states), Asia (three states), Africa } \\
\text { (one state). Population income: high (four states), medium } \\
\text { (four states), low (one state). }\end{array}$ \\
\hline Indicator 6 & $\begin{array}{l}\text { States: Morocco, Switzerland, Republic of Korea, Austria, } \\
\text { Bulgaria, Italy. Location: Europe (four states), Asia (one } \\
\text { state), Africa (one state). } \\
\text { Population income: high (four states), medium (one state), } \\
\text { low (one state). }\end{array}$ & $\begin{array}{l}\text { States: Angola, Chile, Guatemala, Luxembourg, Estonia. } \\
\text { Location: Europe (two states), Africa (one state), Latin } \\
\text { America (two states). Population income: high (three states), } \\
\text { medium (one state), low (one state). }\end{array}$ \\
\hline Indicator 7 & $\begin{array}{l}\text { States: Ecuador, Kazakhstan, Guatemala, USA, Taiwan, } \\
\text { India. Location: Asia (three states), North America (one } \\
\text { state), Latin America (two states). Population income: high } \\
\text { (two states), medium (three states), low (one state). }\end{array}$ & $\begin{array}{l}\text { States: Lebanon, Ireland, Morocco, Poland, Israel, Argentina, } \\
\text { Brazil, Peru. Location: Europe (two states), Asia (two states), } \\
\text { Africa (one state), Latin America (three states). Population } \\
\text { income: high (three states), medium (four states), low (one } \\
\text { state). }\end{array}$ \\
\hline Indicator 8 & $\begin{array}{l}\text { States: Slovenia, Iran, South Africa, Qatar, Guatemala, } \\
\text { Latvia, UAE, Taiwan. Location: Europe (two states), Asia } \\
\text { (four state), Africa (one state), Latin America (one state). } \\
\text { Population income: high (five states), medium (three states). }\end{array}$ & $\begin{array}{l}\text { States: Morocco, Lebanon, Poland, Peru, Puerto Rico, Bosnia } \\
\text { and Herzegovina, Saudi Arabia, Greece. Location: Europe } \\
\text { (three states), Asia (two states), Africa (one state), Latin } \\
\text { America (two states). Population income: high (five states), } \\
\text { medium (two states), low (one state). }\end{array}$ \\
\hline Indicator 9 & $\begin{array}{l}\text { States: Germany, Saudi Arabia, France, USA, Ecuador, } \\
\text { India, Puerto Rico, Morocco. Location: Europe (two states), } \\
\text { Asia (two states), Africa (one states), North America (one } \\
\text { state), Latin America (two states). Population income: high } \\
\text { (five states), medium (one state), low (two states). }\end{array}$ & $\begin{array}{l}\text { States: Ireland, Brazil, Argentina, Israel, Panama, Estonia. } \\
\text { Location: Europe (two states), Asia (one state), Latin America } \\
\text { (three states). Population income: high (four states), medium } \\
\text { (two states). }\end{array}$ \\
\hline
\end{tabular}

Source: Authors got information in this table on the data in table 3. 
Table 4 provides data on the geographic place of states with maximum and minimum values for nine indexes assessed in our research. Analysis of this data shows that we have no evident relationship between such values and geographic place of states and income of people in these states. That is, both maximum and minimum values of indexes are discussed in states placed in various parts of the world and disparity of population income. Thus we proved the accuracy of the second and third hypotheses.

\section{Conclusions}

The aim set in the research, that is, assessment of the indexes showing informal financing of the new SMEs by men and women on the main options, has been achieved. Conclusions of research presenting scientific novelty and originality showed below. Assessment of the indexes describing informal investments in SMEs by men and women in various countries has been carried out. The modeling of the distribution of nine indicators describing external financing for start-up entrepreneurs from male investors and female investors on the three options has been conducted. It has been proven that the proportion of the number of the men included in informal financing of new SMEs created by their relatives in most countries is lower than the same indicator of women. It has been proven that proportion of number men included in informal financing of new SMEs created by their colleagues, as well as friends and neighbors in most countries is higher than the same indicator of women. It has been shown that there is a gender gap for informal financing on all three options. Mean values of nine indexes considered with ranges of their change, characterize most states, have been established. It has been specified that there are substantial country variances in values of nine indexes. States with maximum and minimum values of nine indexes have been represented.

Our results are of theoretical and practical importance for public authorities and entrepreneurship. The methodological approach presented in the article to assessing informal financing of the new SMEs can be applied in a future study.

During our research, we have limitations on empirical information on fact that 59 states are considered.

\section{REFERENCES}

[1] A. Caggese. Financing constraints, radical versus incremental innovation, and aggregate productivity. American Economic Journal: Macroeconomics. No 11(2). P. 275-309. 2019.

[2] M. Godke Veiga, J. McCahery. The Financing of Small and Medium-Sized Enterprises: An Analysis of the Financing
Gap in Brazil. European Business Organization Law Review. No 20. P. 633-664. 2019.

[3] S. Kumar, P. Rao. A conceptual framework for identifying financing preferences of SMEs. Small Enterprise Research. No 22(1). P. 99-112. 2015.

[4] R. Rachmawati, Widowati. Research of the Impact of Financial Dimensions and Entrepreneurial Capacity on Business Performance in Small and Medium Enterprises in Central Java. Universal Journal of Accounting and Finance. Vol. 9. No. 1. P. 122-129. 2021. DOI: 10.13189/ujaf.2021.090113

[5] S. Iriyanto, Suharnomo, M.T. Hidayat, M. Anas. Do Intangible Assets and Innovation Orientation Influence Competitive Advantages? A Case Study of SMEs in Indonesia. Universal Journal of Accounting and Finance. Vol. 9. No. 1. P. 105-115. 2021. DOI: 10.13189/ujaf.2021.090111

[6] M. Campello, M. Larrain. Enlarging the Contracting Space: Collateral Menus, Access to Credit, and Economic Activity. Review of Financial Studies. No 29(2). P. 349-383. 2016.

[7] R. Cole, T. Sokolyk. Who needs credit and who gets credit? Evidence from surveys of small business finances. Journal of Financial Stability. No 24. P. 40-60. 2016.

[8] OECD. High Growth Enterprises. What Governments can do to make a difference? OECD Publishing. 2010.

[9] OECD. Financing SMEs and Entrepreneurs 2012: An OECD Scoreboard, OECD Publishing. 2012.

[10]Z.J. Acs, S. Estrin, T. Mickiewicz, L. Szerb. Entrepreneurship, institutional economics, and economic growth: an ecosystem perspective. Small Business Economics. Vol. 51(2). P. 501-514. 2018.

[11]A. Ferrando, A. Ruggieri. Financial constraints and productivity: evidence from Euro area companies. International Journal of Finance and Economics. Vol. 23(3). P. 257-282. 2018

[12] S. Zubair, R. Kabir, X. Huang. Does the financial crisis change the effect of financing on investment? Evidence from private SMEs. Journal of business research. No 110. P. 456-463. 2020

[13] J.H. Block, M.G. Colombo, D.J. Cumming, S. Vismara. New players in entrepreneurial finance and why they are there. Small Business Economics. Vol. 50. P. 239-250. 2018.

[14] J.A. Elston, S. Chen, A. Weidinger. The role of informal capital on new venture formation and growth in China. Small Business Economics. Vol. 46(1). P. 79-91. 2016.

[15] J. Wu, S. Si, X. Wu. Entrepreneurial finance and innovation: informal debt as an empirical case. Strategic Entrepreneurship Journal. Vol. 10(3). P. 257-273. 2016.

[16]C. Guirkinger. Understanding the coexistence of formal and informal credit markets in Piura, Peru. World Development. Vol. 36(8). P. 1436-1452. 2008.

[17] S. Lee, P. Persson. Financing from family and friends. Review of Financial Studies. Vol. 29(9). P. 2341-2386. 2016.

[18] S. Boucher, C. Guirkinger. Risk, wealth, and sectoral choice in rural credit markets. American Journal of Agricultural Economics. Vol. 89(4). P. 991-1004. 2001. 
[19]T. Beck, L. Lu, R. Yang. Finance and growth for microenterprises: evidence from rural China. World Development. Vol. 67(3). P. 38-56. 2015.

[20]A. Saeed. Formality of financial sources and firm growth: empirical evidence from Brazilian SMEs 1990-2005. Journal of Academic Research in Economics. Vol. 1(2). P. 129-140. 2009.

[21] T. Beck, A. Demirguc-Kuntand, V. Maksimovic. Financing patterns around the world: are small firms different? Journal of Financial Economics. Vol. 89. P. 467-487. 2008.

[22] J.H. Chua, J.J. Chrisman, F. Kellermanns, Z. Wu. Family involvement and new venture debt financing. Journal of Business Venturing. Vol. 26(4). P. 472-488. 2011.

[23] L. Menkhoff, D. Neuberger, O. Rungruxsirivorn. Collateral and its substitutes in emerging markets' lending. Journal of Banking \& Finance. Vol. 36(3). P. 817-834. 2012.

[24] J. Du, A. Guariglia, A. Newman. Do social capital building strategies influence the financing behavior of Chinese private small and medium-sized enterprises? Entrepreneurship: Theory \& Practice. Vol. 39(3). P. 601-631. 2015.

[25] S. Agarwal, R. Hauswald. Distance and private information in lending. The Review of Financial Studies. Vol. 23(7). P. 2757-2788. 2010.

[26] R.W. Anderson, K.G. Nyborg. Financing and corporate growth under repeated moral hazard. Journal of Financial
Intermediation. Vol. 20(1). P. 1-24. 2011.

[27] B. Nguyen, T. Mickiewicz, J. Du. Local governance and business performance in Vietnam: the transaction costs perspective. Regional Studies. Vol. 52(4). P. 542-557. 2018.

[28] T.D. Su, T.M.H. Bui. Government size, public governance and private investment: the case of Vietnamese provinces. Economic Systems. Vol. 41(4). P. 651-666. 2017.

[29] U. Stephan, L.M. Uhlaner, C. Stride. Institutions and social entrepreneurship: the role of institutional voids, institutional support, and institutional configurations. Journal of International Business Studies. Vol. 46(3). P. 308-331. 2015.

[30] A. Lopes, C. Costa. Alternative sources of funding for SMEs in the Portuguese market. AESTIMATIO. The IEB International Journal of Finance. No. 15. P. 138-161. 2017.

[31] A. Moritz, J.H. Block, A. Heinz. Financing patterns of European SMEs- an empirical taxonomy. Venture Capital. Vol. 18(2). P. 115-148. 2016.

[32] Global Entrepreneurship Monitor 2018/2019 Women's Entrepreneurship Report. Global Entrepreneurship Research Association (GERA). London Business School, London, United Kingdom. 2019.

[33] I. Pinkovetskaia, V. Slepova. Estimation of Fixed Capital Investment in SMEs: the Existing Differentiation in the Russian Federation. Business Systems Research. Vol. 9 (1). P. 65-78. 2018. 